\title{
Modern geodetic techniques in the monitoring of historic buildings
}

\author{
Gabriela Kuczyńska*, Magdalena Stawska and Anna Walicka \\ Wroclaw University of Science and Technology, Faculty of Geoengineering, Mining \\ and Geology, 50-370 Wrocław, ul. Wybrzeże Wyspiańskiego 27, Poland
}

\begin{abstract}
Historic buildings constitute a valuable cultural heritage, and at the same time due to the passage of time, they are exposed to a number of adverse factors. In order to preserve them in a non-deteriorated condition, it is necessary to provide comprehensive control of technical condition for these historic buildings, including regular geodetic measurements. This works includes a brief characterisation of the modern measurement techniques, as well as the presentation of possibilities of using the selected techniques for two historic buildings. The first one is the XIII-century cathedral, for which a network for testing vertical displacements was established and an initial measurement was performed. Moreover, a horizontal geodetic control network was implemented, intended for inventory works and the results of measurements were developed, combining angular-linear observations with GNSS vectors. The second building is the XX-century water tower, for which detailed architectural documentation of external walls was prepared on the basis of terrestrial laser scanning. The performed works confirm the need for geodetic monitoring of historic buildings and confirm the effectiveness of used measurement techniques.
\end{abstract}

\section{Introduction}

Historic buildings constitute a valuable cultural heritage of every nation and they are covered by legal protection. The inevitable passage of time results in the deterioration of technical condition of the historic buildings. In order to preserve these buildings in a nondeteriorated condition, it is necessary to undertake systematic preventive, monitoring and repair activities. There's a number of adverse factors that may affect the building, which include: own weight of the structure, additional loads (e.g. wind pressure), dynamic influences (e.g. vibrations), instability of the foundation, changes in temperature and humidity, pressure of water or ice (in the case of buildings located in the vicinity of water reservoirs), mistakes or imperfections made during the construction of the given building or wear and tear of materials from which the building was constructed. Each historic building is characterised by unique specificity and requires individual treatment, as well as a detailed analysis of the impact of other objects located in its vicinity. An inherent element of the

\footnotetext{
* Corresponding author: 227742@student.pwr.edu.pl
} 
monitoring of technical condition of monuments consists of regularly performed geodetic measurements. Modern measurement techniques allow to obtain a detailed description of the geometrical condition of the building, as well as determination of displacements and deformations of the structure with high precision of results.

Geodetic methods of building monitoring are characterized by the possibility to obtain a lot of information, including the determination of numerical characteristics of the building's displacement in space, due to the fixing of local reference systems. Locating the measurement points on the building and in close distance to it, allows to detect the change in the location of the test subject in relation to the surroundings or displacement of the building, along with its surroundings. Displacement of a point is the value determined in the assumed reference system, describing the change of the location of this point in space, which occurred in the specific time interval [1]. A building subject to displacement may change its position via translation or rotation. Deformation is associated with change in the shape of the building, which consists of scale change, twisting, buckling, deflection [2]. In order to detect a change in the position or shape of the monitored building, it is necessary to carry out repetitive measurement cycles, which are aimed at determination of identical values. The results of each periodic measurement are compiled and compared with the values determined in the initial measurement [2].

In addition to monitoring, the historical buildings require the performance of periodic repairs and restoration works. These works are carried out on the basis of documentation originating from the architectural-construction inventory. The above-mentioned documentation allows to recreate the spatial layout of the building and to faithfully reflect the geometry of architectural details. Usually, it consists of photographic images, photogrammetric models, cartographic materials, technical drawings and nowadays - spatial models based on point clouds acquired from the terrestrial laser scanning.

In addition to geodetic methods, the physical methods are also applied, which use specialised measurement equipment that allows for periodic or continuous determination of physical data values, e.g. stress forces, gap sizes. The typical physical devices used to examine changes in the position of the building consist of: strain gauges, extensometers, feeler gauges, dilatometers and clinometers [2].

\section{Selected techniques for geodetic measurement}

\subsection{Geodetic measurements of vertical displacements}

Precise geometric levelling is the basic measurement technique used to determine vertical displacements. The observations cover height differences between the controlled points and reference points, which are interconnected with the use of levelling sections. The set size of reference points and controlled points, as well as their distribution are determined on the basis of the type and extent of the structure, required precision and planned measurement frequency. It is recommended that the levelling sections formed between the reference benchmarks and sections binding the controlled benchmarks should have the length amounting to no more than $250 \mathrm{~m} \mathrm{[2]}$. The precision levellers used for the measurement are characterized by the precision of $0.3 \mathrm{~mm} / \mathrm{km}$ and they perform the measurement automatically from code invar staffs, and then they save it in the internal memory of the instrument. It shortens the measurement time and eliminates incorrect results, which is important in difficult terrain conditions [3].

Vertical displacements can be also determined with the use of precise trigonometric levelling, in which the height difference between measurement points is determined on the basis of the measurement of vertical angle and the spatial distance [2]. However, the trigonometric levelling does not provide such high precision of point height determination 
as precision levelling, therefore it is usually applied in the case, when the controlled points are unavailable or when it is not possible to use precise levelling for safety reasons [4].

\subsection{Geodetic measurements of horizontal displacements}

The purpose of measuring horizontal displacements is to determine the $\Delta x, \Delta y$ components of translation vector for each controlled point in the assumed time interval. These values are calculated as $x, y$ coordinate differences between the initial measurement and the periodic measurement. The specificity of examined building and its immediate surroundings have the greatest impact on the shape of the geodetic network. In extensive geodetic networks, in addition to reference points and controlled points, there are also the so-called tie-points. All these points are usually forming an angular-linear network measured with the use of precise electronic total stations [5]. Sometimes, the method of angular and linear intersections, triangulation or trilateration is used, which allows to obtain very accurate results [6]. Moreover, a static GNSS technique is used to determine horizontal displacements within large areas. Such measurements can be carried out regardless of the time of day and weather conditions. However, it is important to locate the antennas in such manner, so that the visibility to the appropriate number of satellites is ensured. An example of GPS application is demonstrated in [6] and [7]. For small objects, it is also possible to apply the alignment (reference line) method that enables to achieve sub-millimetre precision.

\subsection{Terrestrial laser scanning}

TLS is a measurement technique, which uses reflectorless distance measurement with simultaneous measurement of horizontal and vertical angle. Two types of scanners (pulse and phase) are applied in the field, which differ in the principle of distance measurement, range and speed of measurement, as well as the obtained precision of the resulting $x, y, z$ coordinates. The largest measurement range is characterised by impulse scanners, where the distance to the measured object can reach up to several kilometres [8]. The phase scanners are the fastest and more accurate for short distances. Within one second of measurement, it is possible to obtain even up to a million of points representing the geometrical shape of the measured object. The obtained point cloud can be presented in three coordinate systems: in the local scanner system (SOCS), in the project system determined for several stations (PCS), as well as in the geographic coordinate system (GCS) [9]. The point clouds obtained from measurements at various stations are combined in the registration process, with the use of special signalling targets used during the measurement or the so-called cloud to cloud method. Moreover, colour of the object (on the basis of photos), strength of the laser beam reflection intensity and sometimes the temperature of the object (thermovision) are registered for each point. The data obtained with the use of this technique enables precise determination of the shape and geometry of the tested object, and also enables the creation of its three-dimensional model. Currently, the laser scanning is more and more frequently used in various fields, while its applications mainly include the monitoring of engineering objects and inventory measurements of large objects.

\subsection{Close-range photogrammetry}

Terrestrial photogrammetry allows to construct a three-dimensional model of the object, as well as to determine the changes in the position of the object's points based on the analysis of photographic images taken in a fixed reference system, at a certain time interval. Modern measuring cameras record image on photosensitive CCD or CMOS matrix. Terrestrial 
photogrammetry allows for a quick registration of the object's state, which is important for objects subject to dynamic changes. In the case of determining changes in the position of points on a structure, this method ensures precision of determining the displacements at the level of a few millimetres for an object located $100 \mathrm{~m}$ away, wherein the ratio of photographic base to the length of the section connecting the point on the object with the camera amounts to 1:10. Development of digital image processing software increased the popularity of this measurement technique and enabled the use of non-metric cameras, also in documentation of architecture monument [10].

\subsection{Unmanned aerial vehicles (drones)}

Measurement with the use of unmanned aerial vehicles is used as an independent measurement technique, but also as a supplementation of other techniques. The drones can be equipped with a high-definition camera, RFID reader, GNSS device, wireless Wi-Fi network, as well as infrared, ultrasound or laser scanner [11]. Control over the drone's flight altitude provides the possibility to adjust the data resolution depending on the needs. This method allows access to hard-to-reach elements or elements that are invisible from the ground, e.g. roofs of buildings [12]. Recently, there has been seen a dynamic increase in interest in this method, as well as expansion of application scope, along with the development of this technology [13].

\section{Results}

\subsection{Description of research objects}

The possibilities of using modern geodetic techniques in the monitoring of historic buildings will be presented on the basis of two objects. The first one is the Cathedral of St. John the Baptist in Wroclaw (Poland). It is a Gothic-style building (Fig. 1a), which dates back to XI-XIII century. Over the centuries, this temple was several times destroyed and rebuilt. After the World War II, the cathedral was covered by the protection of a monument conservator. The length of the building amounts to approx. $100 \mathrm{~m}$, its width to approx. $44.6 \mathrm{~m}$, while its height to approx. $97 \mathrm{~m}$. Despite the fact that it is one of the most valuable monuments of the region, this object has not been covered by regular geodetic measurements so far. Moreover, the existing architectural documentation originates from at least several dozen years ago. Therefore, it can be concluded that such an important object of cultural heritage does not have current drawings and results of inventory measurements.

The second one is the historic water tower located in Wroclaw at Wiśniowa street (Fig. 1b). This building was constructed in the years 1903-1904 according to the design of Karl Klimm. Its characteristic feature is the openwork structure, which consists of nine pillars that maintain (as originally intended) the weight of the water reservoir. This object is approx. $20 \mathrm{~m}$ wide and approx. $62 \mathrm{~m}$ high.

\subsection{Establishment of a vertical geodetic control network for the cathedral}

Project of the geodetic control network for determining vertical displacements was prepared jointly with the employees of the Wrocł aw University of Science and Technology, and it was accepted by the city monument conservator. The set of reference benchmarks consisted of three points of the state height control network $(1222,1223,1225)$, as well as the 
adapted point R1 (Fig. 2). The set of controlled benchmarks (Fig. 3) consisted of twenty points (new points numbered 1-19 and the adapted point R24).

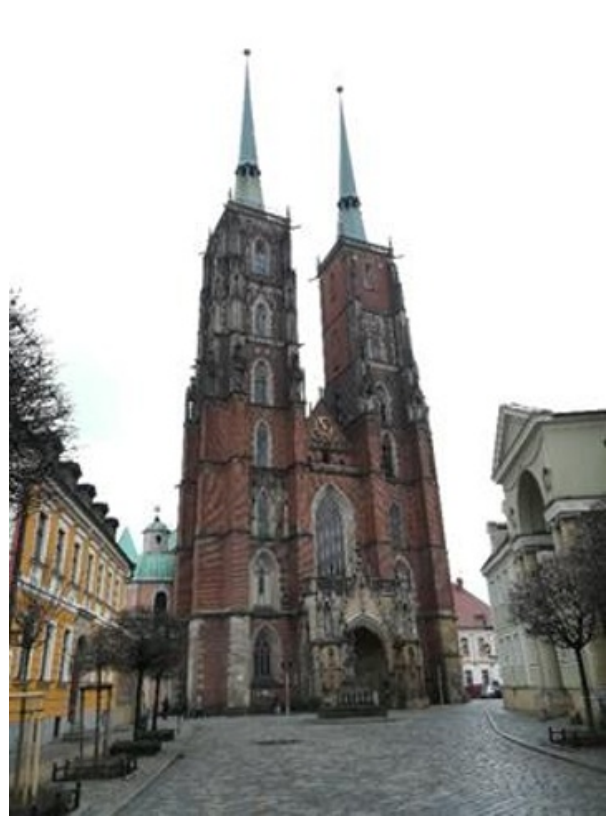

Fig. 1a. Cathedral of St. John the Baptist in Wrocław.

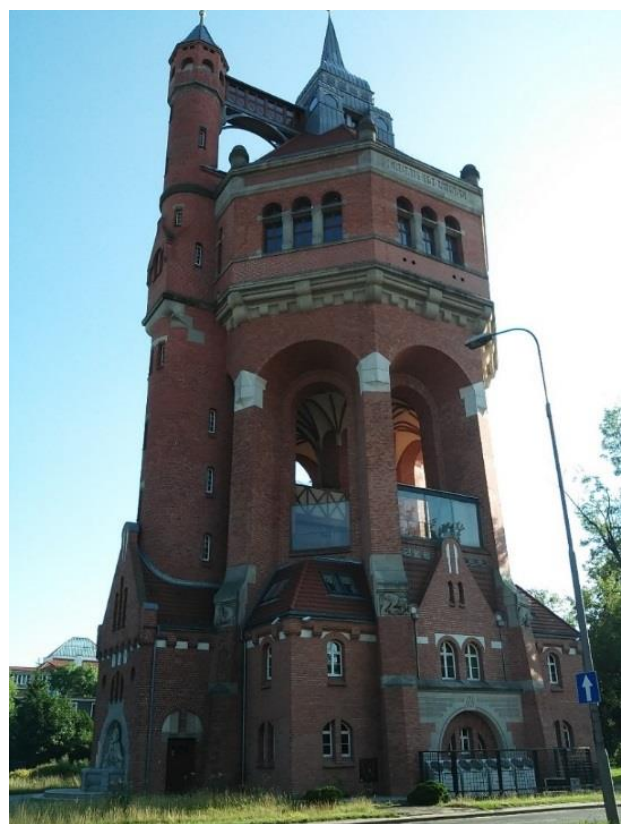

Fig. 1b. Water tower at al. Wiśniowa in Wrocław (Source: Biernat M., Stachyra A.K., 2017)

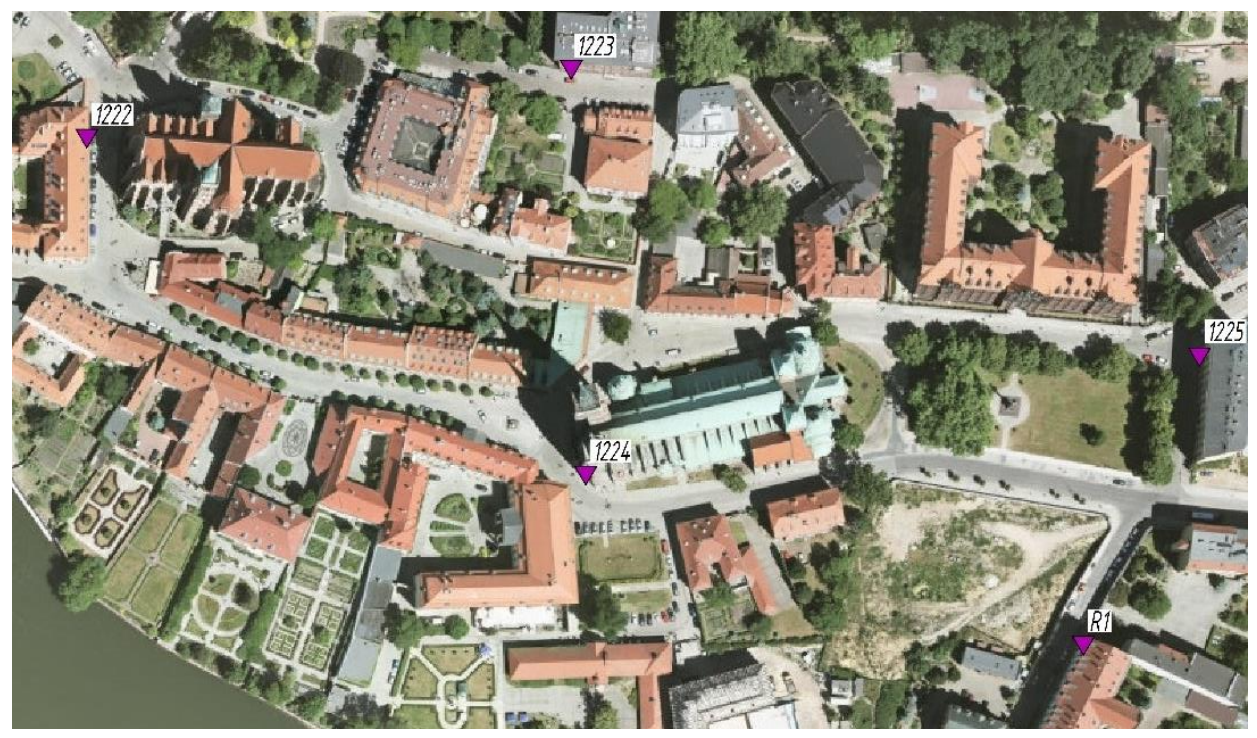

Fig. 2. The location of state benchmarks and adapted R1 benchmark (based on materials from the WMS service provided by the Board of Geodesy, Cartography and Cadastre of the City of Wroclaw) 


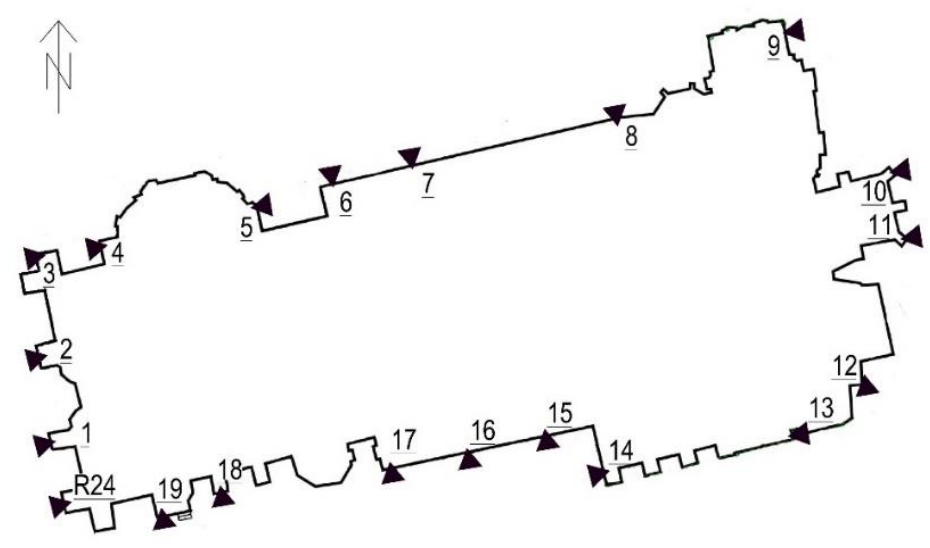

Fig. 3. Sketch of the location of controlled points on the measuring object.

The designed levelling network consisted of 29 sections, which formed 7 closed levelling polygons. The initial measurement was performed on 2-5 January 2019 by applying precision levelling method with the use of Trimble DiNi 0.3 code leveller and the set of invar staffs. Each section was measured in the main and return direction. In the case of longer levelling sections, an even number of stations were used. The collected data was checked and the precision of measurement was estimated on the basis of differences in the height increments, obtained from the double measurement of each section and based on deviations of the closures of levelling polygons. In order to establish a local height system, a free adjustment of the observations between reference benchmarks was carried out with the use of the least squares method. The height error of reference benchmarks after adjustment did not exceed $0.03 \mathrm{~mm}$. Subsequently, the whole network was aligned in the context of binding of reference benchmarks treated as error-free. The height error of controlled benchmarks after adjustment did not exceed $0.12 \mathrm{~mm}$. The height list of all benchmarks from the final adjustment is presented in Table 1 [14].

Table 1. List of coordinates of the geodetic control networks after adjustments

\begin{tabular}{|c|c|c|c|c|c|c|c|}
\hline \multicolumn{3}{|c|}{ Vertical Networks } & \multicolumn{5}{|c|}{ Horizontal Networks } \\
\hline \multirow{2}{*}{$\begin{array}{l}\text { Point } \\
\text { numer }\end{array}$} & $\begin{array}{l}\text { Height of } \\
\text { the point }\end{array}$ & $\begin{array}{l}\text { Height } \\
\text { mean } \\
\text { error }\end{array}$ & \multirow{2}{*}{$\begin{array}{l}\text { Point } \\
\text { numer }\end{array}$} & $\begin{array}{l}\text { Coordinate } X \\
\text { (prefix: } \\
\mathbf{5 6 6 4 0 0 0 ~} \mathbf{~ m )}\end{array}$ & $\begin{array}{c}\mathbf{X} \\
\text { mean } \\
\text { error }\end{array}$ & $\begin{array}{c}\text { Coordinate } Y \\
\text { (prefix: } \\
\mathbf{6 4 3 3 0 0 0 ~ m )}\end{array}$ & $\begin{array}{c}\mathbf{Y} \\
\text { mean } \\
\text { error }\end{array}$ \\
\hline & {$[\mathrm{m}]$} & {$[\mathrm{mm}]$} & & {$[\mathrm{m}]$} & {$[\mathrm{mm}]$} & {$[\mathrm{m}]$} & {$[\mathrm{mm}]$} \\
\hline $\mathrm{R} 1$ & 118.6412 & 0.0 & G1 & 816.888 & 2 & 226.339 & 2 \\
\hline $\mathrm{R} 22$ & 120.1698 & 0.0 & G2 & 775.393 & 1 & 171.214 & 2 \\
\hline $\mathrm{R} 23$ & 120.7075 & 0.0 & $\mathrm{P} 1$ & 748.732 & 1 & 213.763 & 2 \\
\hline $\mathrm{R} 24$ & 121.3171 & 0.1 & $\mathrm{P} 2$ & 758.684 & 2 & 236.947 & 2 \\
\hline $\mathrm{R} 25$ & 118.7650 & 0.0 & $\mathrm{P} 3$ & 754.182 & 2 & 260.238 & 2 \\
\hline 1 & 121.2715 & 0.1 & $\mathrm{P} 4$ & 757.089 & 3 & 275.435 & 3 \\
\hline
\end{tabular}




\begin{tabular}{|c|c|c|c|c|c|c|c|}
\hline 2 & 121.3690 & 0.1 & P5 & 770.311 & 4 & 300.157 & 2 \\
\hline 3 & 121.3503 & 0.1 & P6 & 749.991 & 1 & 228.424 & 2 \\
\hline 4 & 121.3223 & 0.1 & $\mathrm{P} 7$ & 786.441 & 4 & 310.710 & 3 \\
\hline 5 & 121.4278 & 0.1 & P8 & 804.626 & 4 & 311.666 & 3 \\
\hline 6 & 121.3165 & 0.1 & P9 & 814.849 & 4 & 307.338 & 3 \\
\hline 7 & 120.7898 & 0.1 & P10 & 820.438 & 3 & 275.264 & 3 \\
\hline 8 & 120.8460 & 0.1 & P11 & 817.153 & 2 & 244.893 & 3 \\
\hline 9 & 119.7201 & 0.1 & P12 & 804.137 & 2 & 222.268 & 2 \\
\hline 10 & 119.6340 & 0.1 & P13 & 805.770 & 2 & 206.263 & 2 \\
\hline 11 & 119.6953 & 0.1 & P14 & 792.432 & 2 & 189.376 & 2 \\
\hline 12 & 120.0769 & 0.1 & P15 & 783.954 & 2 & 179.219 & 2 \\
\hline 13 & 120.5381 & 0.1 & P16 & 773.505 & 2 & 193.815 & 2 \\
\hline 14 & 120.3675 & 0.1 & P17 & 761.568 & 1 & 194.539 & 2 \\
\hline 15 & 120.5982 & 0.1 & 1677 & 799.755 & 1 & 121.110 & 2 \\
\hline 16 & 121.1489 & 0.1 & 1678.01 & 756.250 & 0 & 210.960 & 0 \\
\hline 17 & 121.5116 & 0.1 & 1679 & 766.861 & 6 & 362.819 & 3 \\
\hline 18 & 121.0940 & 0.1 & & & & & \\
\hline 19 & 121.3152 & 0.1 & & & & & \\
\hline
\end{tabular}

\subsection{Establishment of a horizontal geodetic control network for the cathedral}

In order to enable future inventory works of the cathedral in Wrocł aw, a horizontal control network in the shape of an angular-linear network was established around the object (Fig. 4), taking into account the specificity of the object and its surroundings. During planning of the distribution of points, the integration of measurements performed with the use of electronic total station (Topcon GPT-7503), with precision levelling network and with GNSS satellite measurements performed using static techniques (with Trimble R6 and R8 receivers), as well as future laser scanning, was pursued. For this reason, some points were located opposite the entrance door to the temple, in order to link the scanner positions located outside and inside the object in the future. The established network consisted of 22 points: 17 new points numbered P1-P17 and 5 adapted points (with numbers G1, G2 and three points of the state horizontal control network with the numbers $1677,1678.01,1679)$. The measurements of angular-linear network were carried out on 2-5 January 2019. On the last day, the static GNSS method measurements were carried out in nearly 2-hour measuring campaign at four points: P1, P7, P9, P15. 


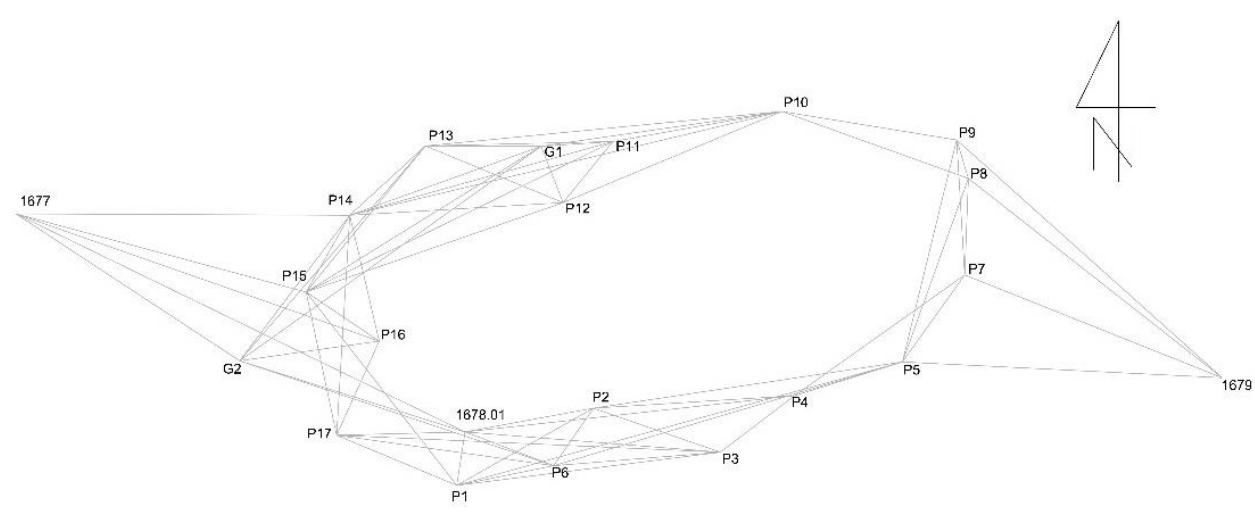

Fig. 4. Established angular - linear network

After initial control of the measurement data, several variants of exact adjustment of the gathered observations were performed with the use of the least squares method. A pseudo-free adjustment that integrates tacheometric data with GNSS vectors and trigonometric levelling were applied. Some of the vectors were rejected due to unsatisfactory precision resulting from difficult measurement conditions (tall buildings and trees obscured the horizon). The final coordinates of the points after adjustment, along with the errors of their determination, are demonstrated in Table 1 [15].

\subsection{Architectural inventory of the water tower}

Terrestrial laser scanning of the water tower was implemented with the use of Leica ScanStation C10 in 2016 as part of the engineer thesis [16]. The obtained registration precision of the scans, based on the control network, amounted to $3 \mathrm{~mm}$. In January 2019, this data was used to prepare a detailed architectural and construction documentation of external walls of the building [17]. With the use of the following software: Cyclone, CloudCompare and AutoCAD, six horizontal projections, two vertical cross-sections and four orthoimages of the elevation were performed. A fragment of the example horizontal projection is presented in Fig. 5 Due to high precision, the performed drawings constitute a proof of the usefulness of application of this measurement technique in the scope of inventory of historic buildings. 


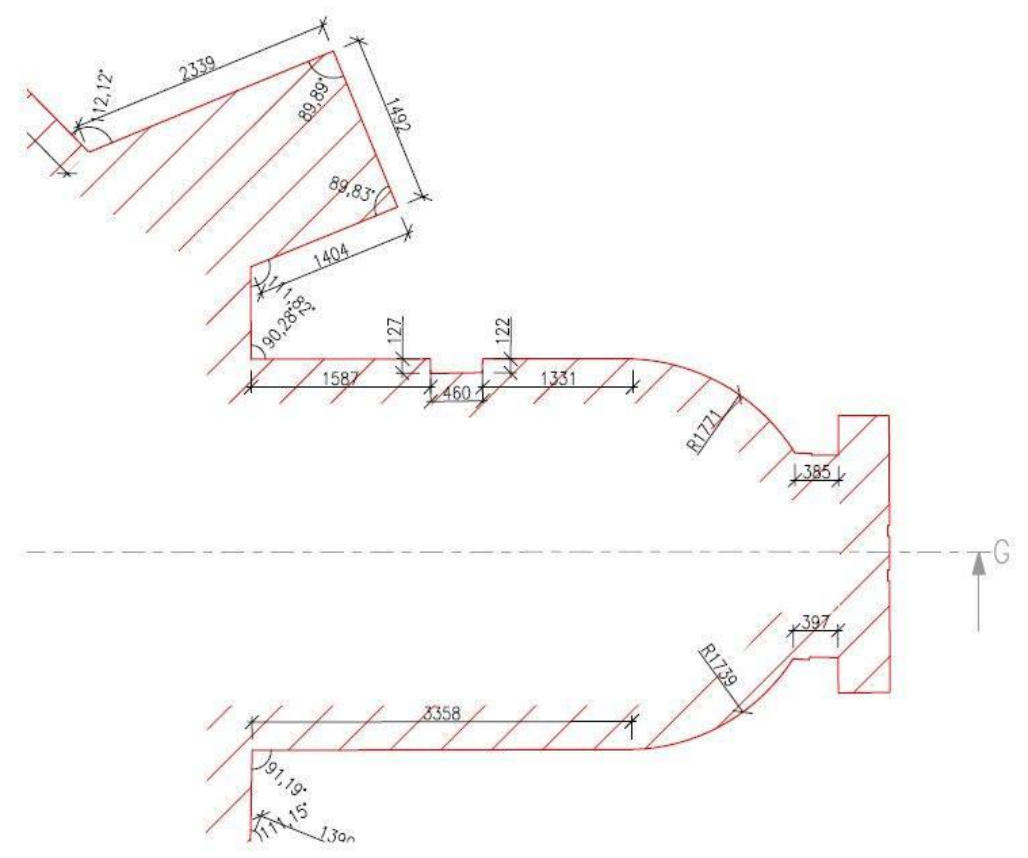

Fig. 5. Fragment of the horizontal cross-section C-C (at the level of $11.50 \mathrm{~m}$ above ground)

\section{Discussion}

The correct designing of the geodetic network is crucial in order to meet the goals of geodetic measurements and in order to achieve the required precision. The correct process of developing the obtained measurement results is also important. In addition to the standard method of least squares, more advanced methods of robust estimation are also used in some cases [18]. The vertical geodetic control network created for the cathedral in Wrocław, as well as the results obtained from the initial measurement constitute the basis for subsequent measurements and they will enable the monitoring of vertical displacements of this valuable building in the future. Simultaneous designing of the horizontal control network allows for conducting detailed inventory works with the use of laser scanning, both outside and inside the cathedral, in the future. An example of effective use of TLS in inventory works is demonstrated on the example of the second historic building, which is the water tower in Wrocław. The performed technical drawings document the current state of the object and will allow for possible restoration works in the future. However, the modern applications of TLS technique are not limited only to inventories. The scanning is more and more widely used to determine displacements, although obtained precision limits some applications [8]. However, there are buildings for which the precision of laser scanning is sufficient. An example of the analysis of suitability of the results from scanning compared to classic techniques for determining horizontal displacements can be found in the work [19]. The use of scanning in order to control the verticality of the industrial chimney is described in the work [20]. The overall image of the chimney geometry obtained from the point cloud allowed to compare the scanner results with two previous measurement campaigns, implemented with the use of the method of surrounding tangents. Due to different heights of measurement levels assumed in the classic measurements, it was not possible to directly compare the results from these two campaigns. 


\section{Conclusions}

The Cathedral of St. John the Baptist in Wrocław is an important monument of Lower Silesia. Covering the cathedral with a regular geodetic monitoring and performing inventory measurements in the future would make it possible to start the efforts aimed at entering the Wrocław cathedral on the list of the Historical Monuments, which includes the monuments of special importance to the culture of the Republic of Poland. The richly decorated water tower is also a special monument of Wrocław. The performed inventory of external walls provided valuable architectural documentation. In the future, the works should be continued and the scanning of the building's interior should be performed.

Regularly performed geodetic measurements are an important element of prevention, which helps to secure the technical condition of historic buildings. Modern measurement techniques allow to achieve a detailed description of the geometric shape of the structure and they allow to detect disturbing changes in its shape. Integration of individual techniques allows to widen the scope of potential applications and it also increases the achieved precision.

\section{References}

1. Standard PN-N-02211:2000 Geodezja - Geodezyjne wyznaczanie przemieszczeń. Geodesy - Displacements determination (In Polish)

2. A. Jagielski, Podstawy geodezji inżynieryjnej, cz. 2. The basics of engineering geodesy, part 2 (GEODPIS, Kraków, 2016) (In Polish)

3. K. Mąkolski, J. Kuchmister, Vertical displacement determination of the vertical buildings situated in the area of Grunwaldzki Square in Wroclaw. Reports on Geodesy, 1/90, 295-303 (2011)

4. P. Gawronek, M. Makuch, Application of classical land surveying measurement methods for determining the vertical displacement of railway bridges. Civil and Environmental Engineering Reports, 27, Issue 4, 169-183 (2017), DOI: 10.1515/ceer2017-0059

5. K. Makowska, P. Kuras, Wykorzystanie pomiarów kątowo - liniowych do badania przemieszczeń zapór wodnych (Wyd. Polskiego Internetowego Informatora Geodezyjnego, Gdańsk, 2016) (In Polish)

6. Q. M. Guedes, S. Irineu, Technical report: Shell dam horizontal displacement monitoring - comparative study using geodetic measurement, optical plumb and GPS technologies. Journal of Applied Geodesy, 3, Issue 4, 249-255 (2009), DOI: 10.1515/JAG.2009.025

7. S. Erol, B. Erol, T. Ayan, A general review of the deformation monitoring techniques and a case study: analysing deformations using GPS/levelling. FIG Working Week, Athens (2004)

8. Z. Muszyński, J. Rybak J, P. Kaczor, Accuracy Assessment of Semi-Automatic Measuring Techniques Applied to Displacement Control in Self-Balanced Pile Capacity Testing Appliance. Sensors, 18, Issue 11, (2018), DOI: 10.3390/s18114067

9. J. Armesto, C. Ordóñez, L. Alejano, P. Arias, Terrestrial laser scanning used to determine the geometry of a granite boulder for stability analysis purposes. Geomorphology, 106, Issues 3-4, 271-277 (2008), DOI: 10.1016/j.geomorph.2008.11.005

10. G. Wojciechowska, J. Luczak, Use of Close-Range Photogrammetry and UAV in Documentation of Architecture Monuments. E3S Web Conf. 71 (2018), DOI: $10.1051 / \mathrm{e} 3$ sconf/20187100017 
11. Y. Srewil, Feasibility of use UAVs (drones) in construction, Institut für Bauinformatik, TU Dresden (2015)

12. K. R, Dayal, I. M. Chauhan, UAV photogrammetry for feature extraction and mapping of corrugated industrial rooftops. The Int. Arch. of the Photogram., Remote Sensing and Spatial Inf. Sciences: XLII-4 (2018), DOI: 10.5194/isprs-archives-xlii-4-129-2018

13. T. R. Thiyab, The Use of Unmanned Aircraft in Aerial Photography in Engineering Geodesy, Journal of Babylon Univ./Eng. Sciences, 25, Issue 5, 1626-1635 (2017)

14. G. Kuczyńska, Zaprojektowanie osnowy geodezyjnej do badania przemieszczeń pionowych zabytkowego obiektu sakralnego oraz wykonanie pomiaru wyjściowego. BSc Thesis, Politechnika Wrocławska (2019) (In Polish)

15. A. Walicka, Zaprojektowanie i wykonanie pomiarów osnowy geodezyjnej stużacej do skanowania laserowego zabytkowego obiektu sakralnego. BSc Thesis, Politechnika Wrocławska (2019) (In Polish)

16. M. Biernat, A. K. Stachyra, Porównanie modeli 3D obiektu architektonicznego utworzonych na podstawie skaningu laserowego oraz niemetrycznych zdjęć cyfrowych. Thesis, Politechnika Wrocławska (2017) (In Polish)

17. M. Stawska, Opracowanie dokumentacji architektoniczno-budowlanej zabytkowego obiektu na podstawie danych $z$ naziemnego skaningu laserowego. BSc Thesis, Politechnika Wrocławska (2019) (In Polish)

18.Z. Muszyński, Application of Selected Robust Estimation Methods for Calculating Vertical Displacements of Hydrotechnical Structures. Studia Geotechnica et Mechanica $\begin{array}{llll}\text { XXXII, No } & \text { No } & \text { (2010), } & \text { available: }\end{array}$ http://www.sgem.pwr.edu.pl/iss/2010/no1/art05_no1_2010.pdf

19.Z. Muszyński, J. Rybak, Evaluation of Terrestrial Laser Scanner Accuracy in the Control of Hydrotechnical Structures. Studia Geotechnica et Mechanica, 39, Issue 4, 45-57 (2017), DOI: 10.1515/sgem-2017-0036

20.Z. Muszyński, W. Milczarek, Application of Terrestrial Laser Scanning to Study the Geometry of Slender Object. IOP Conf. Ser.: Earth Environ. Sci. 95 (2017) DOI: 10.1088/1755-1315/95/4/042069 